\title{
The Development of Cooperative-STAD Based Ebook Teaching Materials in Elementary School Courses for PGSD FIP UNIMED Students
}

\author{
$1^{\text {st }}$ Fajar Sidik Siregar ${ }^{1}, 2^{\text {nd }}$ Arifin Siregar ${ }^{2}, 3^{\text {rd }}$ Daitin Tarigan $^{3}$ \\ \{fajar.sidik@unimed.ac.id ${ }^{1}$, arifinsiregar72@gmail.com ${ }^{2}$, daitintaringan@gmail.com ${ }^{3}$ \} \\ Elementary School Teacher Education, Faculty of Science Education, Universitas Negeri Medan, \\ Indonesia ${ }^{1,2,3}$
}

\begin{abstract}
This study aims to: (1) determine the feasibility of STAD-Cooperative-Based E-Book Teaching Materials in Elementary School Physical Education Course for PGSD FIP UNIMED Students, and (2) to determine student responses to STAD-CooperativeBased E-Book Teaching Materials at Elementary Physical Education Course for PGSD FIP UNIMED Students. The research method used is research and development (R\&D) by adapting the model using a 4-D model (Define, Design, Development and Dissemination). The location of the research was carried out in the PGSD FIP Unimed study program which was located on Jl. Willem Iskandar / Pasar V, Medan. The population of this study were all students of PGSD Unimed batch 2020 totaling 225 students consisting of $11(\mathrm{~A}-\mathrm{K})$ regular and extension classes. The sample of this research was carried out in a class program and one class was chosen, namely the $\mathrm{F}$ Regular 2020 class, which consisted of 40 students. The results showed that the STADCooperative-based e-book teaching materials in the Elementary School Physical Education course that were developed were validated by media expert validators. In phase I, the percentage of eligibility results was $73.80 \%$, which was included in the "appropriate" criteria and in phase II, the results obtained were the percentage of eligibility of $95.20 \%$ is included in the "very feasible" criteria. The results of the material expert validator in stage I the results of the feasibility percentage of $75.55 \%$ included in the "feasible" criteria and in stage II the results of the feasibility percentage of $92.22 \%$ were included in the "very feasible" criteria. At the field trial stage, the effectiveness criteria were achieved with the number of students reaching 40 people in the post-test or about $89.47 \%$. Therefore, it can be concluded that the STAD-Cooperative-based e-book teaching materials in the Elementary School Physical Education course for PGSD FIP UNIMED students are suitable to be used by students during the learning process.
\end{abstract}

Keywords: Teaching Materials, Ebook, Cooperative-STAD, Physical Education.

\section{Introduction}

The progress of a nation is determined by the quality of human energy sources, on the other hand, human energy sources depend on the quality of education. The position of learning is very meaningful to produce a smart, peaceful, open, and democratic society. Therefore, the renewal of learning is very meaningful in order to improve the quality of learning of a nation along with the very rapid growth of Science and Technology (IPTEK), various efforts are taken in order to improve the quality of learning. Education is a learning effort that is carried 
out in a planned manner, with goals that have been planned before and after the implementation process, and evaluated [1].

Lecturers are supporting the implementation of curriculum objectives. The role of the lecturer includes compiling learning tools. Learning devices are a means for lecturers to prepare for the course of lecture activities. Lecturers are required to compile learning tools that are in accordance with the abilities or potentials of students. Effective learning tools are learning tools that are able to make students active in learning activities and students are able to understand the material [2].

Teaching materials or teaching materials are everything that is a curriculum content that must be understood by students with basic competencies to achieve Learning Outcomes and Learning Achievements and Subject Learning Outcomes from each subject in a particular learning unit. For this reason, subject matter is a major part of the educational process, especially in subject-centered teaching, subject matter is the core of educational activities. Learning is carrying out, getting certain experiences in accordance with the desired and expected goals. Through learning experiences, students must be motivated to do something. Through learning and learning activities, this is an effort to improve each student individually. Therefore, education and educational learning need to be designed and addressed to each student, in order to acquire new knowledge needed and can last a long time (retention). Through efforts to design education for individuals and groups of students, basically a change in attitude is achieved for these students [3]. Teaching materials are basically all materials (both data, equipment, and readings) that are systematically arranged, which shows a complete form of competence that students want to understand and use in the educational process with the aim of planning and studying the implementation of education [4]. References for the development of teaching materials can be obtained from various sources, namely personal experience and extracting information from sources, both experts and colleagues. Likewise, we can get references from books, mass media, internet, and others. However, even though the material according to the curriculum is quite abundant, it does not mean that lecturers do not need to develop teaching materials. Because teaching materials developed by lecturers can help students understand the material.

Another consideration is the characteristics of the target. Teaching materials developed by others are usually not suitable for students. There are many reasons for incompatibility, such as society, geography, and culture. Therefore, self-developed textbooks can be adapted to target characteristics. In addition to the social, cultural and geographical environment, the target characteristics also include the stage of student development, initial abilities that have been mastered, interests, and family background. Therefore, self-developed textbooks can be adapted to student characteristics [2].

This type of cooperative learning involves a group of students solving problems in teams, completing tasks or doing something to achieve learning goals and learning outcomes. To optimize physical education learning at Elementary School Teacher Education Faculty of Education, State University of Medan and add types of teaching materials in online learning, it is necessary to develop model-based teaching materials, especially the STAD cooperative learning model.

Cooperative learning tipe STAD is one type of cooperative education model by using small groups with the number of members of each group of 4-5 students heterogeneously [5]. The purpose of developing teaching materials is when in learning activities students can work together with their friends and not only that in terms of teaching teachers to be more creative to improve the skills of students by working in groups. Teaching materials also make students have two responsibilities, namely learning for themselves and helping fellow group members 
to learn. In addition, STAD cooperative teaching materials make the teacher's position more active and focused as a facilitator, mediator, motivator, and evaluator.

One of the efforts to overcome this problem is by utilizing developing teaching materials used in ongoing learning activities. One of the teaching materials to gain practicality, effectiveness and efficiency (without spending a lot of money) is non-printed e-book-based teaching materials. The world of ebook is currently becoming a trend that makes it easier for writers to spread their work easily. With this technology in mind, you can imagine the cost of an e-book is not as expensive as a book. Based on the problems above, the researcher provides an alternative in an effort to increase cooperation in Physical Education lectures, namely through the development of Ebook teaching materials based on the STAD-cooperative model. So that teaching activities are more effective and achieve learning objectives based on standard abilities and basic abilities [5]. Based on the explanation above, the author will conduct a research entitled "Development Of Stad-Cooperative Ebook Teaching Materials for Elementary School Physical Education Courses".

\section{Method}

The type of research used in this research is research and development (R\&D). R\&D is a research method used to produce a particular product and test the effectiveness of that product. Research and development, or research and development $(\mathrm{R} \& \mathrm{D})$, is product-oriented in the field of education. This is done to help teachers deliver learning materials more effectively. Research and development or research and development is research that produces certain products and tests these products.

This study aims to develop Ebook teaching materials using the STAD type Cooperative model in Elementary School Physical Education Courses. The research procedure uses the Research \& Development (R\&D) model of the 4-D (Define, Design, Development and Dissemination) model. Described in the image below.

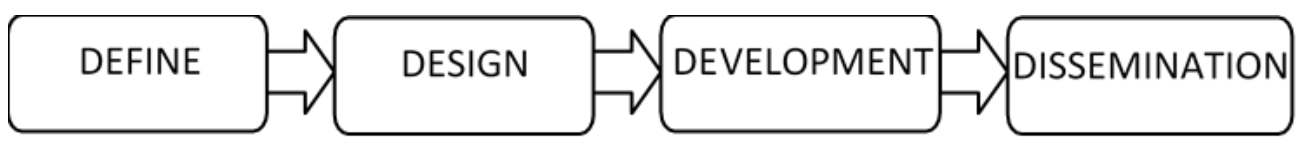

Fig. 1. Research and Development Steps [6].

Based on Figure 1. the explanation is given as follows. Define Contains activities to determine which products will be developed and their specifications. Design (design) includes the activity of designing a predetermined product. Development includes activities to make a design into a product and test the effectiveness of the product repeatedly until the product is produced according to the specified specifications. Dissemination includes activities to disseminate test products for the benefit of others.

Research and development produces products in the form of objects (hardware) and also in forms (software). The products developed can be in the form of e-book teaching materials, and STAD-type cooperative-based learning models. In this study, researchers produce products in the form of objects (hardware) and also in the form of (software). The product developed in this research and development is in the form of Cooperative-stad-based E-Book teaching materials in Elementary School Physical Education courses. This research was 
conducted to assist lecturers in delivering subject matter to students and researchers hoped that students would be able to more easily understand the subject matter.

The location of the research was carried out in the Elementary School Teacher Education study program Faculty of Education, State University of Medan which was located on Jl. Willem Iskandar / Pasar V, Medan. The population of this research is all students of Elementary School Teacher Education study program Faculty of Education, State University of Medan class of 2020 totaling 225 students consisting of 11 (A-K) regular and extension classes. The sample of this research was carried out in a class program and one class was chosen, namely the F Regular 2020 class, which consisted of 40 students.

\section{Results and Discussion}

The results of the media validation assessment after making revisions obtained a score of 119 with a percentage of feasibility of $95.20 \%$. STAD-Cooperative Ebook Teaching Materials for Physical Education Courses are included in the "Very Appropriate" category to be used without any further revisions. The two results of the validation of teaching materials obtained different percentages. Each validation stage shows an increase in the developed teaching materials.

The results of the material validation assessment after making revisions obtained a score of 83 with a feasibility percentage of $92.22 \%$. STAD-Cooperative Ebook Teaching Materials for Physical Education Courses are included in the "Very Appropriate" category to be used without any further revisions. The two results of material validation obtained a score of 109 obtaining different percentages. Each validation stage shows an increase in the STADCooperative Ebook Teaching Materials in the Physical Education Course that is developed.

Based on the results of individual trials conducted on 3 Regular F class 2020 students, totaling 3 students, namely getting an average score of 1 which is in the "good" category, meaning that STAD-Cooperative Ebook Teaching Materials in Physical Education Courses get the predicate good assessment as a teaching material in the learning process. The results of the assessment can be concluded that the assessment of the feasibility of STAD-CooperativeBased Ebook Teaching Materials in Physical Education Courses is based on the results of the assessment of individual trial subjects, namely in the "good" category of each question item. After passing the individual trial, the STAD-Cooperative Ebook Teaching Material in the Physical Education Course was continued to the small group trial stage.

Based on the results of individual trials conducted on 3 Regular F class 2020 students, totaling 3 people, namely getting an average score of 1 which is in the "good" category, meaning that STAD-Cooperative-Based E-Book Teaching Materials in Physical Education Courses get the predicate good as teaching materials in the learning process. The results of the assessment can be concluded that the assessment of the feasibility of STAD-CooperativeBased E-Book Teaching Materials in Physical Education Courses is based on the results of the assessment of individual trial subjects, which is in the "good" category. After passing the individual trial, the STAD-Cooperative-Based E-Book Teaching Material in the Physical Education Course was continued to the small group trial stage. Based on small groups conducted to 10 students of class F Regular 2020, namely getting an average score of 1, namely the "good" category. Explained that STAD-Cooperative Ebook Teaching Materials in Elementary School Physical Education Subjects received an assessment predicate with good grades as teaching materials in the group learning process. The results of the small group 
calculation explained that the assessment of the feasibility of the STAD-Cooperative Ebook Teaching Materials in the Elementary School Physical Education Course on the small group trial subject was the "good" category.

This research is a type of Research and Development $(R \& D)$ research. The development model used in this research is the 4-D (Four D Models) suggested by Thiagarajan are Define, Design, Development and Disseminate. From the development procedure using the 4D model. Development Of Stad-Cooperative Ebook Teaching Materials for Elementary School Physical Education Courses from the results of validation data from teaching materials experts, material experts and student responses. The acquisition of eligibility data is described as follows: 1) The data obtained from the results of the expert validation of teaching materials in the first stage carried out obtained a score of 91 and the percentage of feasibility results was $73.80 \%$ included in the "Eligible" criteria and had to be revised again. Furthermore, the second stage of validation obtained a score of 119 and the percentage of $95.20 \%$ feasibility results included in the "Very Eligible" category used without any revision. 2) The data obtained from the results of the material expert validation obtained a score of 68 and the percentage of the feasibility results was $75.55 \%$ included in the "Eligible" criteria and had to be revised again. Furthermore, the second stage of validation obtained a score of 83 and the percentage of feasibility results was $92.22 \%$. included in the "Very Appropriate" category to be used without any revision. 3) The data obtained from the results of practitioner validation obtained a score of 108 and the percentage of feasibility results was $98.18 \%$ included in the "Very Eligible" category and can be used without any revision.

In addition to being based on the validation expert assessment, the feasibility of learning teaching materials can be seen from the student's response to the use of teaching materials during the learning process. Therefore, the researchers distributed student response questionnaires to theTeaching materials in individual trials and small group trials to see student responses to Development Of Stad-Cooperative Ebook Teaching Materials for Elementary School Physical Education Courses. From the results of individual trials conducted on 3 students of class F 2020 an average score of 1 which is in the "good" category, meaning that Development Of STAD-Cooperative Ebook Teaching Materials for Elementary School Physical Education Courses received an assessment predicate with good grades as a medium of learning in the teaching and learning process. The results of the small group trial conducted on 10 students of class F Stambuk 2020 got an average score of 1 which was in the "good" category, meaning that STAD-Cooperative-Based Ebook Teaching Materials for Physical Education Course received an assessment predicate with good grades as teaching materials in the group learning process. Based on the results of the validation expert assessment and student responses to the Development Of Stad-Cooperative Ebook Teaching Materials for Elementary School Physical Education Courses can be said to be suitable for use.

Effectiveness Development Of STAD-Cooperative Ebook Teaching Materials for Elementary School Physical Education Courses through product trials, product trials carried out namely field trials. At this stage the researcher measures the effectiveness of the use of Development Of STAD-Cooperative Ebook Teaching Materials for Elementary School Physical Education Courses in learning using learning outcomes tests. Furthermore, in product trials, learning activities are carried out such as online learning activities with reference to RPS which will be delivered directly by online class lecturers. In explaining the material, the lecturer will use teaching materials as a learning support tool. After finished using Development Of STAD-Cooperative Ebook Teaching Materials for Elementary School Physical Education Courses, students are given a post-test to see the learning outcomes after 
using STAD-Cooperative-Based E-Book Teaching Materials for Elementary Physical Education Course.The field trial phase was carried out in class F Stambuk 2020 with a total of 19 students. The effectiveness criteria are met or said to be good if students who achieve completeness are greater than or equal to $85 \%$. Based on the field trials that have been carried out, the effectiveness criteria are achieved with the number of students reaching 17 people in the post-test or about $89.47 \%$. Meanwhile, at the time of the pre-test, 13 students achieved completeness or about $68.42 \%$. This shows that the completeness of 17 students after learning using STAD-Cooperative-Based E-Book Teaching Materials for Elementary Physical Education Course increased than the pre-test, which was $21.05 \%$. So it can be concluded that learning using STAD-Cooperative-Based E-Book Teaching Materials for Elementary Physical Education Course that have been developed can improve student learning outcomes.

\section{Conclusion}

The conclusion of this study is that the results of the feasibility of developing STAD Cooperative Ebook Teaching Materials for Elementary School Physical Education from material experts obtained an average of $92.22 \%$ which was included in the very feasible category and media experts obtained an average of $98.18 \%$ which was included in the very decent category. The Effectiveness of Developing STAD-Cooperative Ebook Teaching Materials for Elementary School Physical Education Subjects Through Learning Outcomes Test Instruments. Based on the average student learning outcomes, it was concluded that the use of Stad-Cooperative Ebook Development for Elementary School Physical Education Subjects could improve student learning outcomes with the pre-test results increasing by $21.05 \%$.

\section{References}

[1] Sriyani, et al. Implementation of PBKB in Thematic Learning to Improve Social Attitudes and Learning Outcomes of Elementary School Students. e-journal of the Graduate Program of Ganesha University of Education Basic Education Study Program. 2017; 3.

[2] Sari D, Muhsinah A, Wilda I. Development of a Science Module on the Relationship of Living Things and Their Environment Based on a Contextual Approach. J Sci Lanterns. 2018:28-37.

[3] Herlina, Acim, Mishnah, Khairunnisa R. Need Analysis of Using Google Forms For Learning. J1 Educ Educ. 2019; 7(2):143-150.

[4] Prastowo A. Develop an Integrated Thematic Learning Implementation Plan: Implementation of the 2013 Curriculum for SD/MI. Jakarta: Kencana Prenada Media Group; 2015. 298.

[5] Trianto. Design of Thematic Learning Development for Kindergarten/RA \& Elementary Elementary School/MI Early Years. Jakarta: Kencana; 2018.

[6] Thiagarajan S, Semmel DS, Semmel MI. Instructional Development for Training Teachers of Exceptional Children. Indiana: Indiana University Bloomington; 1974. 